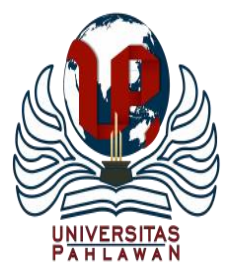

Edukatif : Jurnal Ilmu Pendidikan Volume 3 Nomor 4 Tahun 2021 Halm 1587 - 1593

EDUKATIF: JURNAL ILMU PENDIDIKAN

Research \& Learning in Education

https://edukatif.org/index.php/edukatif/index

\title{
Peningkatan Motivasi Belajar Melalui Media Audiovisual Berbantuan Power Point Pada Peserta Didik Di Sekolah Dasar
}

\author{
Andina Widhayanti ${ }^{1 凶}$, Muhammad Abduh ${ }^{2}$ \\ Universitas Muhammadiyah Surakarta, Indonesia ${ }^{1,2}$ \\ E-mail : andinawidh69@gmail.com ${ }^{1}, \underline{\text { ma123@ums.ac.id }}^{2}$
}

\begin{abstract}
Abstrak
Penelitian ini didasarkan atas permasalahan yang terjadi di kelas IV SD Negeri Wonobodro 01 yaitu rendahnya motivasi belajar IPS. Tujuan penelitian yang ingin dicapai yaitu meningkatkan motivasi belajar IPS melalui media audiovisual berbantuan power point. Jenis penelitian ini adalah penelitian tindakan kelas dengan analisis data kualitatif. Teknik pengumpulan data pada penelitian ini adalah angket, observasi dan dokumentasi. Hasil penelitian ini menunjukkan bahwa hasil rata-rata motivasi belajar peserta didik kelas IV SD Negeri Wonobodro 01 Tahun pelajaran 2020/2021 pada pra siklus sebesar $42 \%$. Setelah dilakukan tindakan rata-rata motivasi belajar meningkat sebesar $68 \%$ dan selanjutnya dilakukan tindakan perbaikan rata-rata motivasi belajar meningkat menjadi $82 \%$. Hal ini berarti melalui media audiovisual berbantuan power point dapat meningkatkan motivasi belajar peserta didik kelas IV SD Negeri Wonobodro 01 Tahun Pelajaran 2020/2021.
\end{abstract}

Kata Kunci: Berbantuan power point, audiovisual media, motivasi belajar, peserta didik kelas IV

\begin{abstract}
This research is based on the problems that occurred in 4th graders SD Negeri Wonobodro 01, namely the low motivation to learn social studies. The research objective to be achieved is to improve social studies motivation by using power point-assisted audiovisual media. This type of research is classroom action research with qualitative data analysis. Data collection techniques in this study were questionnaires, observation, and documentation. The results of this study indicate that the average result of the learning motivation of 4th graders in the pre-cycle is $42 \%$. After the action was taken, the average learning motivation increased by $68 \%$, and then corrected the average learning motivation increased to $82 \%$. This means that using power point-assisted audiovisual media can improve the learning motivation for 4 th graders SD Negeri Wonobodro 01 the academic year 2020/2021.
\end{abstract}

Keywords: Power point-assisted, Audiovisual media, Learning motivation, $4^{\text {th }}$ graders

Copyright (c) 2021 Andina Widhayanti, Muhammad Abduh

$\triangle$ Corresponding author:

Email : andinawidh69@gmail.com

DOI $\quad:$ https://doi.org/10.31004/edukatif.v3i4.627

ISSN 2656-8063 (Media Cetak)

ISSN 2656-8071 (Media Online)

Edukatif : Jurnal Ilmu Pendidikan Vol 3 No 4 Tahun 2021 p-ISSN 2656-8063 e-ISSN 2656-8071 
1588 Peningkatan Motivasi Belajar Melalui Media Audiovisual Berbantuan Power Point Pada Peserta Didik Di Sekolah Dasar - Andina Widhayanti, Muhammad Abduh

DOI: https://doi.org/10.31004/edukatif.v3i4.627

\section{PENDAHULUAN}

Pendidikan merupakan suatu kebutuhan yang harus dipenuhi dalam kehidupan bermasyarakat, berbangsa dan bernegara. Pendidikan sejatinya sangat dibutuhkan oleh setiap manusia. Majunya suatu bangsa banyak ditentukan oleh kualitas pendidikan bangsa itu sendiri, karena pendidikan sebagai upaya mencetak sumber daya manusia yang berkualitas dan berdedikasi tinggi. Pendidikan adalah usaha sadar dan terencana untuk mewujudkan suasana belajar dan proses pembelajaran agar peserta didik secara aktif mengembangkan potensi dirinya untuk memiliki kekuatan spriritual kegamaan, pengendalian diri, kepribadian, kecerdasan, akhlak mulia serta keterampilan yang diperlukan dirinya, masyarakat, bangsa dan negara (Undang-Undang No 20 Tahun 2003). Guru senantiasa menciptakan suasana belajar bagi peserta didiknya supaya peserta didik mengembangkan potensi yang dimilikinya.

Pada masa pandemi, peserta didik dapat belajar melalui pembelajaran daring. Pembelajaran daring mengharuskan guru, peserta didik dan orang tua untuk menguasai teknologi. Penggunaan teknologi digital dalam pendidikan memungkinkan guru dan peserta didik melaksanakan proses pembelajaran walaupun berada ditempat yang berbeda (Milman, 2015: 567) melalui pembelajaran daring sehingga tujuan pembelajaran dapat tercapai. Tercapainya tujuan pembelajaran perlu adanya motivasi belajar peserta didik. Pembelajaran secara daring dapat diakses dimana saja dan kapan saja sehingga mampu membuat peserta didik belajar mandiri dan motivasinya meningkat (Sadikin and Hamidah 2020: 220). Motivasi adalah kekuatan yang ada dalam diri seseorang yang menyebabkan orang tersebut mempunyai inisiatif untuk melakukan sesuatu dan berperilaku tertentu (Wibowo, 2015: 161) untuk mencapai keberhasilan (Sarangi, 2015: 140). Motivasi dapat diartikan sebagai energi seseorang yang menimbulkan tingkat persistensi dan antusiasmenya dalam melaksanakan suatu kegiatan, baik yang bersumber dari dalam diri individu (motivasi intrinsik) maupun dari luar individu (motivasi ekstrinsik) (Kompri, 2015: 61) yang memberi semangat sehingga dapat mencapai tujuan (Wardani \& Setyadi, 2020: 74). Tetapi masih ada kendala dalam pelaksanaan pembelajaran daring.

Data yang dihimpun oleh Komisi Perlindungan Anak Indonesia (KPAI), sejak 16 Maret 2020 bahwa telah menerima 213 pengaduan baik dari orang tua atau peserta didik terkait pembelajaran daring/jarak jauh (Fitria, 2020). Pengaduan terkait pembelajaran daring seperti penugasan yang terlalu berat yang harus diselesaikan dalam waktu yang singkat, tugas merangkum dan menyalin dari buku peserta didik yang banyak, waktu belajar yang masih kaku, minimnya kuota untuk mengikuti pembelajaran daring dan sebagian peserta didik tidak mempunyai smartphone untuk mengikuti pembelajaran. Peserta didik kelas IV SD Negeri Wonobodro mengalami kendala saat belajar melalui pembelajaran daring dan terlalu lama melakukan pembelajaran daring sehingga mengalami kebosanan. Hal ini dapat dilihat saat peserta didik kurang aktif dalam belajar dan tidak tepat waktu dalam mengumpulkan tugas. Tidak semua peserta didik dapat melakukan pembelajaran daring karena beberapa kendala seperti ketersediaan perangkat keras (smartphone), jaringan sinyal, kemampuan menguasai teknologi dan motivasi belajar saat daring. Penanaman pembelajaran secara kontekstual sangat diperlukan. Menurut Nurhadi pembelajaran kontekstual adalah konsep belajar yang mendorong guru untuk menghubungkan antara materi dan situasi dunia nyata peserta didik serta juga mendorong peserta didik membuat hubungan antara pengetahuan yang dimilikinya dan penerapannya dalam kehidupan mereka sendiri-sendiri (Sugiyanto, 2008: 18).

Pembelajaran IPS bertujuan untuk supaya peserta didik mampu mengembangkan pengetahuan dan keterampilan dasar yang dapat dimanfaatkan untuk dirinya dalam kehidupannya sehari-hari. Di kehidupan sehari-hari, peserta didik sebagai makhluk sosial saling berhubungan dan berinteraksi. Dalam berinteraksi tersebut, peserta didik dituntut untuk mengetahui nilai dan norma yang berlaku dalam masyarakat dan mengenal keragaman budaya, suku, bahasa, dan agama. Selain itu, peserta didik juga berinteraksi dengan lingkungan alam. Peserta didik harus mengetahui bagaimana cara berinteraksi yang baik dengan lingkungan alam seperti bagaimana mengolah sumber daya alam. Pengetahuan yang harus diperoleh peserta didik terkait 
1589 Peningkatan Motivasi Belajar Melalui Media Audiovisual Berbantuan Power Point Pada Peserta Didik Di Sekolah Dasar - Andina Widhayanti, Muhammad Abduh

DOI: https://doi.org/10.31004/edukatif.v3i4.627

hal tersebut yaitu dengan memperlajari muatan pelajaran IPS. IPS adalah mata pelajaran di sekolah yang di desain atas dasar fenomena, masalah dan realitas sosial dengan pendekatan interdisipliner yang melibatkan berbagai cabang ilmu-ilmu sosial dan humaniora (Mukminan, 2017: 2). IPS sebagai mata pelajaraan yang berisi perpaduan dari berbagai disiplin ilmu sosial serta menuntut pengajaran yang terpadu IPS sehingga batas atau sekat dari berbagai disiplin ilmu sosial dalam mata pelajaran ini tidak terlalu terlihat dengan jelas (Wahidmurni, 2017: 5). Guru harus menyajikan materi dalam muatan pelajaran IPS secara nyata supaya peserta didik selalu mengingat dan memahaminya. Keterampilan guru mengharuskan untuk mengembangkan perangkat pembelajaran yang inovatif dan kreatif yang mampu membawa peserta didik terus berada dalam suasana belajar. Pembelajaran daring dengan memanfaatkan teknologi khusunya dalam penyajian media pembelajaran sangat dibutukan. Penggunaan media audiovisual selama pembelajaran daring di sekolah dasar sangat efektif (Salsabila, Seviarica, and Hikmah 2020: 302). Penggunaan media dalam proses pembelajaran dengan memanfaatkan perkembangan teknologi (Hae et al., 2021: 856) akan memiliki pengaruh positif terhadap peningkatan motivasi belajarnya (Puspitarini et al., 2019: 60). Dengan adanya motivasi belajar akan memudahkan peserta didik dalam mencapai harapan dan cita - cita dalam belajar. Terlebih sekarang terdapat kemudahan dalam belajar dengan perkembangan teknologi.

Penelitian ini bertujuan untuk meningkatkan motivasi peserta didik kelas IV di SD Negeri Wonobodro 01 menggunakan media audiovisual berbantuan power point. Setelah melaksanakan tindakan kelas, diharapkan mampu meningkatkan motivasi belajar peserta didik sehingga guru mampu mengembangkan media pembelajaran untuk meningkatkan ketertarikan peserta didik dalam proses belajar.

\section{METODE PENELITIAN}

Penelitian ini merupakan penelitian tindakan kelas (PTK). Penelitian tindakan dilaksanakan untuk memecahkan masalah dalam kelas dengan tindakan nyata dalam suatu siklus. Penelitian dilaksanakan di SD Negeri Wonobodro 01 pada 24 peserta didik kelas IV A. Teknik pengumpulan data yang digunakan diantaranya angket, observasi, dan dokumentasi. Angket ini dibagikan kepada peserta didik untuk mengetahui motivasi belajar dalam pembelajaran IPS melalui media audiovisual berbantuan power point. Kegiatan observasi dalam penelitian ini berupa proses belajar peserta didik kelas IV saat pembelajaran melalui media audiovisual berbantuan power point. Adapun dokumen yang dibutuhkan berupa daftar nilai peserta didik, foto dan video saat berlangsungnya penelitian tindakan kelas.

Instrumen pengumpulan data dari angket yang diberikan terdiri dari pertanyaan motivasi belajar dengan indikator optimis, minat, hasrat dan keinginan berhasil, tekun dalam menghadapi tugas dan kegiatan menarik dalam belajar. Setiap indikator terdiri dari tiga pertanyaan tertutup. Teknik analisis data digunakan untuk menganalisis data-data yang sudah dikumpulkan berdasarkan jawaban peserta didik. Dalam penelitian tindakan kelas ini menggunakan analisis deskritif kualitatif. Prosedur penelitian tindakan kelas dilaksanakan dalam dua siklus dengan tahapan setiap siklusnya terdiri dari perencanaan, pelaksanaan, observasi dan refleksi.

\section{HASIL DAN PEMBAHASAN PENELITIAN}

Proses pembelajaraan saat ini dilaksanakan dengan dalam jaringan (daring) hal ini disebabkan di Indonesia sedang mengalami situasi pandemi Covid-19. Pandemi covid yang ada saat ini mengakibatkan terganggunya proses pembelajaran tatap muka di sekolah. Proses kegiatan belajar mengajar di sekolah menjadi pembelajaran jarak jauh. Pembelajaran jarak jauh sat ini menimbulkan beberapa kekurangan salah satunya membuat peserta didik kurang berminat dan tertarik dalam pembelajaran. Peserta didik bosan mengikuti pembelajaran dan terlambat dalam mengumpulkan tugas. Fakta tersebut menerangkan tanda-tanda tentang motivasi belajar yang masih rendah pada peserta didik. Sehingga guru harus menciptakan suasana belajar yang menyenangkan dengan membuat media pembelajaran untuk membantu proses belajar mengajar 
agar peserta didik tetap berkonsentrasi dalam mencapai tujuan belajar. Media belajar dianggap sebagai salah satu solusi yang dapat membantu guru dalam menciptakan lingkungan belajar yang menyenangkan dan tidak membosaankan untuk peserta didik selama pembelajaran daring. Media pembelajaran yang digunakan yaitu media audiovisual berbantuan power point.

Peneliti menggunakan indikator optimis, minat, hasrat dan keinginan berhasil, tekun dalam menghadapi tugas dan kegiatan menarik dalam belajar untuk meningkatkan motivasi belajar peserta didik kelas IV. Hasil angket awal didapatkan informasi mengenai motivasi belajar dengan persentase indikator optimis sebesar $43 \%$, indikator minat sebesar $42 \%$, indikator hasrat dan keinginan berhasil sebesar $38 \%$, indikator tekun dalam menghadapi tugas sebesar 51\% dan indikator kegiatan menarik dalam belajar sebesar 39\%. Secara keseluruhan dari lima indikator tersebut mencapai rata-rata sebesar $42 \%$.

Hasil proses pembelajaran pada siklus I bahwa media audiovisual berbantuan power point mampu meningkatkan motivasi belajar peserta didik dengan persentase indikator optimis $55 \%$, minat $67 \%$, hasrat dan keinginan berhasil 59\%, tekun dalam menghadapi tugas $73 \%$ dan kegiatan menarik dalam belajar $86 \%$. Ratarata dari kelima indikator sebesar $68 \%$. Peningkatan terjadi pada setiap indikator motivasi belajar. Setelah dilaksanakan tindakan proses pembalajaran pada siklus I diperoleh data tentang motivasi belajar peserta didik mengalami peningkatan tetapi belum secara maksimal. Oleh karena itu, dilakukan perbaikan tindakan pada siklus II.

Pada pelaksanaan tindakan di siklus II diperoleh data motivasi belajar dengan persentase setiap indikator optimis $73 \%$, minat $82 \%$, hasrat dan keinginan berhasil $78 \%$, tekun dalam menghadapi tugas $86 \%$ dan kegiatan menarik dalam belajar 93\%. Rata-rata dari kelima indikator sebesar $82 \%$.

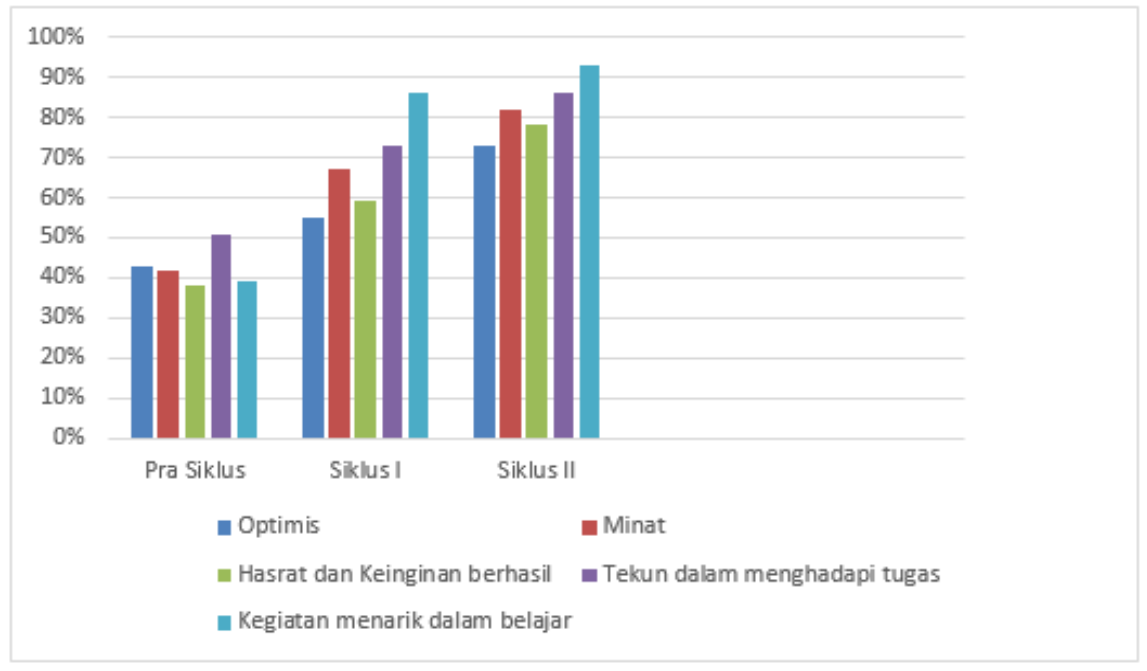

\section{Diagram 1. Diagram peningkatan motivasi belajar setiap indikator}

Motivasi belajar IPS peserta didik kelas IV SD Negeri Wonobodro 01 dapat ditingkatkan dengan mengunakan media audiovisual berbantuan power point. Media audiovisual merupakan gabungan antara audio dan visual. Media audiovisual mampu menyalurkan pesan dengan memanfaatkan indera pendengaran dan indera penglihatan (Sukiman, 2012: 184). Media audiovisual dapat digunakan untuk menyampaikan pesan melalui kegiatan mendengar dan melihat sehingga dalam proses pembelajaran lebih efektif dan mencapai tujuan pembelajaran. Contoh media audiovisual salah satunya berbantuan microsoft power point. Microsoft Power Point merupakan program presentasi yang di kembangkan oleh Microsoft Office dan di tampilkan ke layar mengunakan bantuan LCD proyektor (Hujair, 2013: 135) yang dapat digunakan untuk persentasi ataupun media pembelajaran di sekolah. Dengan media audiovisual berbantuan power point, guru dapat dengan mudah mentransfer ilmu melalui presentasi materi sehingga membantu peserta didik tetap fokus dengan materi yang diterangkan dan memudahkan guru menguasai kelas (Warkintin \& Mulyadi, 2019: 83 
1591 Peningkatan Motivasi Belajar Melalui Media Audiovisual Berbantuan Power Point Pada Peserta Didik Di Sekolah Dasar - Andina Widhayanti, Muhammad Abduh

DOI: https://doi.org/10.31004/edukatif.v3i4.627

Penggunaan media pembelajaran yang tepat sesuai karakteristik anak SD dapat mendorong peningkatan motivasi belajar peserta didik, (Widyasari \& Rafsanjani, 2021: 1178). Hal tersebut terlihat pada tingkat optimis, minat, hasrat dan keinginan berhasil peserta didik, tekun dalam menghadapi tugas dan kegiatan menarik dalam belajar yang terus meningkat di setiap siklusnya.

Motivasi peserta didik terlihat dari 1) optimis untuk memperoleh nilai yang baik dengan jawaban yang sudah dikerjakan serta tidak terpengaruh oleh jawaban teman, 2) berminat bertanya, menjawab dalam mendengarkan penjelasan guru dengan baik. Kondisi ini seperti penelitian yang dilakukan Hendrawan (2017) penggunaan media audiovisal dapat meningkatkan keaktifan peserta didik seperti bekerja kelompok, berpendapat, bertanya dan menjawab pertanyaan, 3) peserta didik memiliki hasrat dan keinginan untuk berhasil dengan tetap semangat belajar tanpa menunggu perintah dari guru, 4) Peserta didik tekun dalam menghadapi tugas dengan mengerjakannya tepat waktu dan teliti, 5) Peserta didik tertarik dan senang karena guru dalam proses pembelajaran menggunakan media audiovisual berbantuan power point. Hal serupa juga selaras dengan penelitian Syarwah et al., (2019) menunjukkan hasil bahwa media audio visual mampu meningkatkan motivasi belajar peserta didik dan membuat peserta didik menjadi penasaran, tertarik dan akhirnya peserta didik memperhatikan sehingga pembelajaran tidak membosankan.

Menurut Salsabila, Seviarica, and Hikmah (2020) media audiovisual sangat mempengaruhi motivasi belajar peserta didik karena karakteristiknya yang berbasis gambar dan suara, sehingga mempermudah peserta didik dalam memahami materi. Sedangkan menurut Mutmainnah (2018) terjadi peningkatan motivasi belajar peserta didik dalam mata pelajaran IPS pada materi pembahasan tentang penampakan alam di kelas IV SD Negeri Cibeber II tahun pelajaran 2017/2018. Peningkatan skor motivasi belajar dari terlihat dari kondisi awal 56,70 (sedang), pada siklus I menjadi 62,52 (sedang), pada siklus II menjadi 65,19 (sedang) dan pada siklus III menjadi 74,34 (tinggi). Setelah dilaksanakan penelitian ini, terjadi peningkatan motivasi belajar pada peserta didik kelas IV SD Negeri Wonobodro 01 dalam materi sumber daya alam dengan berbantuan power point. Media audiovisual power point yang digunakan memuat materi sumber daya alam pada tema 6 CitaCitaku dan soal. Penambahan soal dan permainan interaktif berbantuan power point menjadi hal yang berbeda dengan media pembelajaran audiovisual lainnya. Peserta didik tertarik mengikuti pembelajaran karena disajikan gambar, video, dan soal latihan. Berdasarkan pelaksanaan penelitian ini, ada beberapa keterbatasan yang dialami peneliti diantaranya penelitian hanya difokuskan pada muatan pelajaran IPS, ada peserta didik yang masuk keluar ruang virtual pembelajaran karena masalah sinyal dan pembelajaran menggunakan smartphone sehingga tampilan terbatas pada layar smartphone peserta didik. Penggunaan media audiovisual berbantuan power point mampu membuat peserta didik tertarik mengikuti pembelajaran dan memperjelas penyampaian materi oleh guru sehingga mempermudah memahaman peserta didik.

\section{KESIMPULAN}

Berdasarkan penelitian yang sudah dilakukan tentang penerapan media audiovisual berbantuan power point mampu meningkatkan motivasi belajar IPS kelas IV SD Negeri Wonobodro 01. Terjadi peningkatan motivasi belajar dari $42 \%$ pada pra siklus, $68 \%$ pada siklus I dan meningkat menjadi $82 \%$ pada siklus II. Setiap siklusnya mengalami peningkatan signifikan. Motivasi peserta didik terlihat dari optimis untuk memperoleh nilai yang baik dengan jawaban yang sudah dikerjakan serta tidak terpengaruh oleh jawaban teman, berminat bertanya, menjawab dalam mendengarkan penjelasan guru dengan baik, peserta didik memiliki hasrat dan keinginan untuk berhasil dengan tetap semangat belajar tanpa menunggu perintah dari guru, peserta didik tekun dalam menghadapi tugas dengan mengerjakannya tepat waktu dan teliti, dan peserta didik tertarik dan senang karena guru dalam proses pembelajaran menggunakan media audiovisual berbantuan power point. Guru dapat menggunakan media pembelajaran audiovisual berbantuan power point karena mampu meningkatkan motivasi belajar peserta didik di semua kelas dan muatan pembelajaran lainnya. 
1592 Peningkatan Motivasi Belajar Melalui Media Audiovisual Berbantuan Power Point Pada Peserta Didik Di Sekolah Dasar-Andina Widhayanti, Muhammad Abduh

DOI: https://doi.org/10.31004/edukatif.v3i4.627

\section{DAFTAR PUSTAKA}

Fitria, Chusna Farisa. 2020. "KPAI Terima 213 Pengaduan Pembelajaran Jarak Jauh, Mayoritas Keluhkan Beratnya Tugas Dari Guru." https://nasional.kompas.com/read/2020/04/13/15584711/kpai-terima-213pengaduan-pembelajaran-jarak-jauh-mayoritas-keluhkan?page=all (May 3, 2021).

Hae, Yonathan, Year Rezeki, and Patricia Tantu. 2021. "EDUKATIF : JURNAL ILMU PENDIDIKAN Penerapan Media Pembelajaran Visual Dalam Membangun Motivasi Belajar Siswa Sekolah Dasar." 3(4): $1177-84$.

Hendrawan, Wiwin. 2017. "Upaya Meningkatkan Hasil Belajar Ips Melalui Penggunaan Media Audio-Visual Pada Siswa Kelas Ivb Sd Negeri I Blunyahan.” Jurnal Pendidikan Guru Sekolah Dasar 6(6): 611-18.

Hujair, Sanaki. 2013. Media Pembelajaran Interaktif Inovatif. Yogyakarta: Kaukaba.

Kompri. 2015. Motivasi Pembelajaran Perspektif Guru Dan Siswa. Bandung: PT Remaja Rosdakarya Offset.

Milman, M. B. 2015. "Distance Education." In International Encyclopedia of the Social \& Behavioral Sciences: Second Edition.

Mukminan, Edy Surahman. 2017. "Peran Guru Ips Sebagai Pendidik Dan Pengajar Dalam Meningkatkan Sikap Sosial Dan Tanggung Jawab Sosial Siswa SMP.” Harmoni Sosial 4(1): 1-13. http://journal.uny.ac.id/index.php/hsjpi.

Mutmainnah. 2018. "Penggunaan Media Pembelajaran Power Point Untuk Sekolah Dasar." Jurnal Teknologi Pendidikan dan Pembelajaran 5(2): 123-30.

Puspitarini, Yanuari Dwi, and Muhammad Hanif. 2019. "Using Learning Media to Increase Learning Motivation in Elementary School." Anatolian Journal of Education 4(2): 53-60.

Sadikin, Ali, and Afreni Hamidah. 2020. "Pembelajaran Daring Di Tengah Wabah Covid-19." Biodik 6(2): $109-19$.

Salsabila, Unik Hanifah, Hilda Putri Seviarica, and Maulida Nurul Hikmah. 2020. "Urgensi Penggunaan Media Audiovisual Dalam Meningkatkan Motivasi Pembelajaran Daring Di Sekolah Dasar." INSANIA: Jurnal Pemikiran Alternatif Kependidikan 25(2): 284-304. http://www.ejournal.iainpurwokerto.ac.id/index.php/insania/article/view/4221.

Sarangi, C. 2015. "Achievement Motivation Of The High School Students: A Case Study Among Different Communities Of Goalpara District Of Assam." Journal of Education and Pratice 6(19).

Sugiyanto. 2008. Model-Model Pembelajaran Inovatif. Surakarta: PSG Rayon 13.

Sukiman. 2012. Pengembangan Media Pembelajaran. Yogyakarta: PT Pustaka Insan Madani.

Syarwah, Resi Amelia, Moh Fauzaiddin, and Adityawarman Hidayat. 2019. "Peningkatan Motivasi Belajar Siswa Menggunakan Media Audio Visual Pada Pembelajaran Bahasa Indonesia." Jurnal Pendidikan Tambusai 3(5): 936-45.

Undang-Undang No 20. 2003. Sistem Pendidikan Nasional. Bandung: Citra Umbara.

Wahidmurni. 2017. Metodologi Pembelajaran IPS. Yogyakarta: Ar-Ruzz Media.

Wardani, Krisma Widi, and Danang Setyadi. 2020. "Pengembangan Media Pembelajaran Matematika Berbasis Macromedia Flash Materi Luas Dan Keliling Untuk Meningkatkan Motivasi Belajar Siswa." Scholaria: Jurnal Pendidikan dan Kebudayaan 10(1): 73-84.

Warkintin, Warkintin, and Yohanes Berkhamas Mulyadi. 2019. "Pengembangan Bahan Ajar Berbasis CD Interaktif Power Point Untuk Meningkatkan Hasil Belajar Siswa." Scholaria: Jurnal Pendidikan dan Kebudayaan 9(1): 82-92.

Wibowo, Krisno Prastyo. 2015. "Penerapan Model Make a Match Berbantuan Media Untuk Meningkatkan Motivasi Dan Hasil Belajar IPS.” Jurnal Pendidikan IPS 2(2): 158-69. 
1593 Peningkatan Motivasi Belajar Melalui Media Audiovisual Berbantuan Power Point Pada Peserta Didik Di Sekolah Dasar - Andina Widhayanti, Muhammad Abduh

DOI: https://doi.org/10.31004/edukatif.v3i4.627

Widyasari, Lidya Angie, and Mohamad Arief Rafsanjani. 2021. "EDUKATIF: JURNAL ILMU PENDIDIKAN Apakah Penerapan Blanded Learning Dapat Meningkatkan Motivasi Dan Hasil Belajar Siswa Dalam Pembelajaran Jarak Jauh ?" 3(3): 854-64. 